\title{
Exploring customer satisfaction with university cafeteria food services. An empirical study of Temptation Restaurant at Taylor's University, Malaysia
}

https://doi.org/10.1515/ejthr-2017-0009

received May 22, 2017; accepted October 20, 2017
Keywords: Customer Satisfaction; Service Quality; Food and Beverage Quality; Ambience; Price; Value

\section{Introduction}

Food services are an important constituent of wholesome arrangement that influences personal satisfaction of students and faculty at universities and colleges. Food service requirements of university students need to be further researched. While the significance of offering quality education is undisputed for many universities and colleges that are concerned with bringing more undergraduates to their institutions, paying thoughtful attention to food services is an additional attraction for students. Further, the number of undergraduates registered in universities is growing incessantly, causing an explosive development of this market (Garg, 2014). University students' needs become especially vital at the present time because universities and colleges are largely concerned with retaining students who have numerous options available to them. While the significance of offering excellent teaching is supreme for these universities and colleges, a number of university administrators are starting to perceive and value the idea of offering complete services in the campus in which food services can assume a fundamental part. One of the example in this regard would be religion and ethnicity that adds to food selections and the resulting satisfaction of the consumer. In the event that the kind of food available to the students may not appeal to them or be inappropriate to their taste, it could be a reason for them to become dissatisfied with the institution.

Saglik, Gulluce, Kaya, and Ozhan (2014) established that in order to survive in today's aggressive market, all food service operations must give importance to the quality of service offered to its customers since food service quality is viewed as a compelling variable in fulfilling stu- 
dents' expectations (Raman \& Chinniah, 2011). Additionally, they have to research other vital quality prerequisites, for example, food and beverage quality, as well as price and value fairness, in order to be able to satisfy students (Joung, Lee, Kim, Ahn, \& Huffman, 2011). A study conducted by researchers (Meyer \& Conklin, 1998; Woo, Ng, \& Kim, 2009; Deshpande, Basil, \& Basil, 2009) has reported that food taste, price, nutrition, and comfort were some of the components used for food selection among adults. The study also focused on assortment, quality, convenience, operating hours and price and value fairness. As an indicator of the quality of services provided, these evaluations can assist the university and college cafeterias in providing enhanced food services.

The probability of customers returning to a restaurant is regularly assessed. $\mathrm{Ng}$ (2005) mentioned that a consumer's gratification is frequently used as a pointer since it leads to repeat patronage, brand loyalty and creates new clienteles (Oh, 2000; Yuksel \& Yuksel, 2002) which, thus, prompts to an establishment's future income and benefits (Qin \& Prybutok, 2009). While there is no assurance of a satisfied customer's repeat visit, it is almost sure that an unsatisfied client will not return. Other than food quality, price and value are likewise vital elements impacting a student's satisfaction in university dining services. $\mathrm{Ng}$ (2005) found that price and value did alone lead to positive result. When price works as a marker of quality, the value is perceived (Soriano, 2003).

The current study is distinctive as it represents a well-intentioned investigation of the effects of numerous dining experiences on consumer satisfaction within the student and staff customer viewpoints comprising two distinctive demographic segments. This study benefits in filling up the gap in the body of knowledge of students and staff opinions and behaviours about the university cafeteria food service. This study also extends university cafeteria administrators' understanding of the vital role of dining experiences in building an effective marketing strategy. Therefore, the aim of current study is to investigate the relationships among restaurant experiences and customer satisfaction according to different age groups in university cafeteria segment. More specifically, the objectives of the study are:

- To examine the relationship between restaurant experiences and customer satisfaction.

- Investigate which restaurant experiences are most important to student and staff customers for customer satisfaction.

\section{Literature review}

\subsection{The development of university food services in Malaysia}

Institutional food services in Malaysia are now provided in various sectors like schools, hospital facilities, child and senior care centres, colleges and university dining halls. In general, to the best of our knowledge there is little evidence or absence of literature on university food services in Malaysia. Presently, the interest in institutional food service, mainly in university food services, in Malaysia has developed continuously as the number of students is increasing on campus. Currently, institutional food service, particularly in universities, is mushrooming as the student population in public and private universities in Malaysia is expanding. Thus, it becomes imperative for the universities and other higher education institutions to offer the finest food and beverage products to the staff and students (Li, 2008; Baharun, Awang, and Padlee, 2010).

On reviewing the existing literature, we observed that many factors have been found to influence students and staff when choosing a food service property, such as the quality of food and beverages, quality of service, value, price, hygiene and cleanliness, location, and product variety. For the purpose of the current study, factors that have been investigated in relation to their impact on consumer satisfaction are food and beverage quality, food and beverage variety, service quality, the atmospherics of the restaurant and the price-to-value relationship.

It is believed that service quality has a positive effect on customer satisfaction, that is to say improving service quality results in a satisfied customer (Chang, Suki, \& Nalini, 2014; Lee, Liaw, Lee, \& Rha, 2016). But of course, service quality is not the only variable to consider when explaining customer satisfaction, as pricing also plays a central role in the analysis of customer satisfaction. While the relationship between quality and customer satisfaction, price fairness and satisfaction have been pretty well determined by service marketing researchers, it seems that no clear links have been established between these two variables for research on satisfaction. But the reality is that quality and price are actually the two most important factors when customers decide to purchase the service (Xi \& Shuai, 2009). 


\subsection{Customer satisfaction}

Customer satisfaction has been studied for a long time by hundreds of researchers. Consumer loyalty is the core of any business promotion. Consumer loyalty frequently turns into the focal point of consideration since it is used to decide a customer's repeat buying expectation, which is in turn used for the turnover or profit prediction of any business. The aptitude to please clientele is crucial for restaurants or for any other business. Thus the client's decision to choose a restaurant product or service is based on the ability of that service or product to deliver a pleasant customer satisfaction. The fundamental idea of customer satisfaction was at first seen as a decent indicator of customer's future purchase intentions. Amelia and Garg (2016) noted that first impression is one of the main considerations along with the quality of food, waiting time for the food being served, correctness of the food served, and politeness and alertness of restaurant staff. Comfortable seating and dining area and restaurant ambience had significantly affected the customers' intention to return to the restaurant. Apart from the above-mentioned attributes, brand familiarity and brand loyalty are also associated with customer satisfaction since when customers are happy with all of these characteristics, there is certainly a revisit intention (Paswan, Spears, \& Ganesh, 2007; Tam, 2008; Qin \& Prybutok, 2009). Along with customer satisfaction in restaurants, the students' satisfaction in university cafeterias is also becoming popular and important, as students make up the majority as users of institutional food services particularly in university and college dining. Students' satisfaction in university cafeterias completely relies upon the quality of food and beverage served at cafeterias, food and beverage variety and choices and price and value fairness (Ng, 2005; Xi \& Shuai, 2009).

\subsection{Food and beverage quality}

Food and beverage quality plays a vital role in determining and forming students' satisfaction. Quality attributes of food and beverage such as taste, smell, freshness, appearance, size, shape, colour, gloss, consistency, and texture play a higher role in accomplishing or surpassing customer satisfaction and expectation to return (Dollah, Mansor, \& Mohamed, 2012). In food service businesses, the food products chosen for display and sale by caterers are selected for their colour and appearance attributes. These attributes help to draw consumer attention and later impact the decision on whether or not to buy. Colour and other appearance features generate customers' first impression in a food service business. Food and beverage quality is categorised as one of the essential elements of customer satisfaction and is an effective indicator of customer's intention to return again to a specific restaurant. Lee (2004) and Andaleeb and Caskey (2007) found that most students noted that they would deal with on-campus food services more often in the case of the improvement of food and beverage quality. In shaping customers' satisfaction, it is imperative for the food service administrators to profoundly comprehend their necessities and requests, particularly in institutional food service industry, for example, in university dining (Ng, 2005; Xi \& Shuai, 2009). Overall quality of the food and beverage, the taste of food and beverage, freshness of the food and beverage products and visual appeal of the food and beverage are categorised under food quality measurement.

H1: Food and beverage quality offered at university cafeteria has a significant relationship to customer satisfaction.

\subsection{Food and beverage variety}

The appearance and form of foods have an emotional impact on our palates, moods and internal well-being, and due to this food and beverage operations must encourage flavour by producing a meal that tastes great, is healthy and looks astonishing. "The menu is the number one tool and is the purest form of a restaurants strategic marketing plan” (McCall \& Lynn, 2008). Menus initiate the process for customers to visit restaurants. It serves as a first impression and can express a lot about the outlet. It is common that food and beverages are studied jointly in research on influences of context on consumer choice (e.g., Jaegar, Marshall, \& Dawson, 2009; Bisogni, et al., 2007; DellaValle, Roe, \& Rolls, 2005). Since food and beverages are generally consumed together, this is not inappropriate. The study of contextual influences on food and beverage choices - "why does who eat what, when and where?" - is of great significance to better comprehend the multifaceted relationship of food choice drivers (Koster, 2009). It is highly important that the food service operations have a good variety of choices in their menus that will give its patrons more options to choose from. The good variety of food and beverage is a significant factor that drives customer's satisfaction. In the case of university cafeterias, offering a good variety of food choices will help to attract the students and the staff to dine in and will stop them to look for other options at off-campus food service operations. 
H2: Food and beverage variety offered at university cafeteria has a significant relationship with customer satisfaction.

\subsection{Service quality}

Service quality can be studied as a phenomenon considered within the perspective of relating customers' expectations and perceptions regarding the provided service (Yllmaz 2008; Tan, Oriade, \& Fallon, 2014). Inkumsah (2011) added that quality of service considerably affects customer satisfaction. Similarly, Garg (2014) felt that customer service can inspire customer opinion towards a restaurant. In other words, service quality can be determined by customers' expectations and perceptions of service. The same service can be seen as low quality by a customer and as high quality by another customer, depending on the customer's perception of the service offered. Andaleeb and Caskey (2007) mentioned in their study that, students' requirements and opinions relating to the service quality differ from student to student and also from one semester to another. Consequently, this variance prompts to a more confusing and opposing business environment, which results in difficulty to measure service quality. Tan, Oriade, and Fallon (2014) likewise specified that this intangible element was one of the vital components in service quality. Service quality is difficult and complex to be measured because services are intangible. The intangible facets could be the employees' performance, their responsiveness towards customer's problems or issues, thoughtfulness, and politeness of the employees to the customers. It is very important for the food and beverage service providers to upgrade the quality of service provided to the students and the staff at the campus outlets. This will discourage them from looking for options off-campus. They are also not constrained to on-campus food service quality, as they know about encompassing food service quality (Andaleeb \& Caskey, 2007).

H3: Service quality offered at university cafeteria has a significant relationship with the level of customer satisfaction.

\subsection{Price and value}

It is noteworthy that students have constrained financial resources that influence their choices of picking food service operations, as they ceaselessly look for reasonable expenses. For the students, price plays a major role while choosing a restaurant as they have restricted finances. Similarly, Nadzirah, Ab-Karim, Ghazali, and Othman (2013) agreed that cost is the primary factor in university food service operations since students prefer to purchase food and beverage at a cheaper price. Likewise, they indicated that if the costs of the food and beverages are too high for students in the university or college campus, the students will choose to buy food and beverages from less expensive off-campus food service operations. Receiving the right value for money paid is amongst the most imperative variables that urge the students to return to a food service operation, resulting in student satisfaction. Nadzirah et al. (2013) proposed that the food service administrators must improve food and beverage menu with more rational prices. This will ensure that the staff and the students consume food and beverage from university cafeteria, rather than buying food products from other and off-campus food service operations. This will also lead to a higher customer satisfaction. Also, Soriano (2003) stated that the clients' quality desires rely upon the cost they pay for the service and when the cost increases, the quality desires will increase accordingly. A few researchers categorise cost and values as price fairness. Fairness is the judgment of whether a result and the procedure to achieve a result are sensible or satisfactory (Bolton \& Shankar, 2003).

H4: Price and value fairness offered at university cafeteria has a significant relationship with the level of customer satisfaction.

\subsection{Atmospherics}

Cafeteria atmosphere is dictated by the spatial organisation of the seating, variety of the internal decorations and the appropriateness of the ambient melodies, which are imperative providers to the higher gratification of cafeterias (Namkung \& Jang, 2008). Besides, food packing, portion size, and arrangement lighting at the cafeteria impact the individual's prompt setting (Story, Kaphingst, Robinson-O'Brien, \& Glanz, 2008). Additionally, the physical setting impacts customers' view of service quality (Hensley \& Sulek, 2007; Norhati \& Nur Hafisah, 2013). Previous research by Flegal, Carroll, Ogden, \& Curtin (2010) found that there are connections between food information, food quality, eating behaviour, dining situations and food distribution settings. The atmosphere is an intangible component made up of everything related to the brand that will yield an impression towards the specific location. The design of the dining setting, stylistic layout, interior design and colour scheme, textures and the food produce 
the atmosphere. The appropriate atmosphere can make the food, service quality and entire dining experience appear to be better (Raman \& Chinniah, 2011; Norhati \& Hafisah, 2013). All these elements are most crucial and have a direct association with customer's perception.

H5: Atmospherics has a significant relationship on the level of customer satisfaction with the university cafeteria.

\subsection{Conceptual framework}

The suggested framework used for this study comprised of five independent variables and one dependent variable. The suggested framework is demonstrated in Figure 1.

\section{Research methodology}

\subsection{Research approach and sampling method}

The aim of current research is to investigate the relationships among restaurant experiences and customer satisfaction according to different age groups in the university cafeteria segment. Thus, so as to empirically examine the proposed hypotheses, a quantitative research approach, based on the distribution of questionnaires and online surveys, was undertaken in this study. The aggregate populace of this study comprised of all students who were enrolled at Taylor's University, Malaysia, along with the

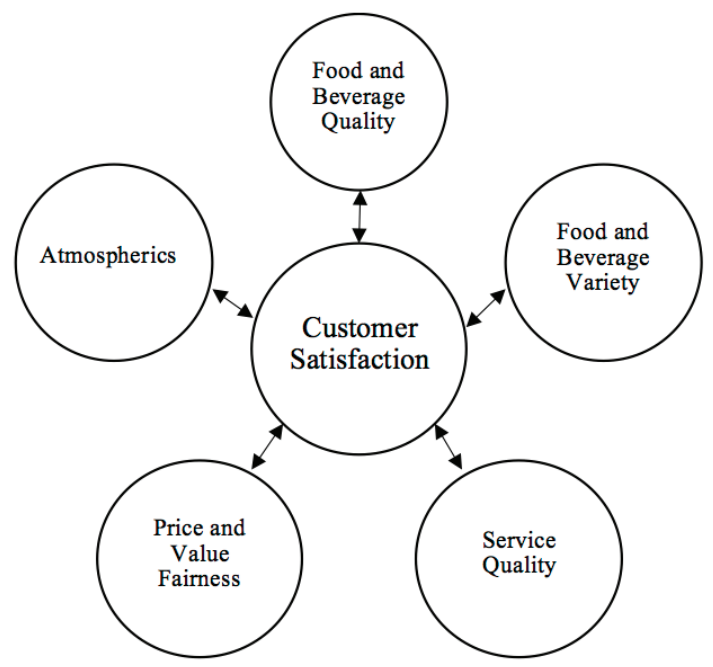

academic and admin staff working at Taylor's University. As there are more than 10,000 students enrolled in various faculties of Taylor's University, it was challenging to use random sampling methods. Thus, a stratified random probability sampling method was applied, so that each member of the population has an equal and known chance of being selected.

The survey instrument used for the current study is comprised of six parts. The first part consisted of nine statements and aimed at measuring students' perceptions of quality of food and beverages offered at the cafeteria. The second part was designed to measure respondents' perception about food and beverage variety offered in the cafeteria and consisted of five statements. The third part comprised of eighteen statements, aimed at measuring respondents' service quality perceptions in the cafeteria. The fourth part of the questionnaire was designed to understand respondents' perception about price and value fairness and consisted of five statements. The fifth part focused on the statements related to the ambience of the cafeteria and involved sixteen statements. The last section consisted of ten questions and intended at collecting demographic and behavior characteristics information of the respondents (students and staff). The measurement scale of the questionnaire for all statements in part one to part five was based on 5-Likert scale, and that scale ranges from ' 1 ' being 'strongly disagree' to ' 5 ' being 'strongly agree'.

To guarantee a high response rate, two methods were used for data collection. First, the researcher, with the assistance of the cafeteria manager and the assistant manager, approached students and staff from different faculties in the cafeteria and asked them in person to fill out a brief questionnaire. Another method of data collection was through the design of an Internet-based questionnaire, which was posted to university students as a link through social media (https://docs.google. com/forms/d/13uyJwPHvEPhuANOba95e5e_rR5bgoR8kc9KZZ4GfP10/edit). Participation was voluntary and anonymity was ensured. Respondents were invited to participate in the study during the period from the last week of November to mid-December 2016, and a total of 301 questionnaires were collected. Out of them, seven questionnaires were invalid, and therefore the total number of valid questionnaires was 294 .

Figure 1: Conceptual framework of the study 


\section{Findings and discussion}

The collected data was compiled and analysed using the Statistical Package for the Social Science (SPSS) version 20. SPSS was used for reliability analysis, descriptive analysis and correlation analysis to test the hypotheses. In order to accomplish the objective of this study, different statistical tests, such as frequencies, means of scores, and coefficients of Pearson correlations were used. Frequencies were first computed to examine demographic and behavioural characteristics of the respondents. Second, means of scores were calculated in order to gauge students' perceptions regarding different service attributes. Third, Pearson correlation coefficients were calculated to measure the existence and degree of significant relationships between different research variables.

\subsection{Reliability analysis}

Reliability is the extent to which a measure will produce consistent results. The internal reliability of the measurement instrument is commonly assessed by Cronbach's alpha. A Cronbach's alpha of 0.70 or higher indicates that the measurement scale that is used to measure a construct is reliable (Nunnally, 1967; Schmitt, 1996). Table 1 demonstrates that the overall reliability (internal consistency) of the study was found to have a coefficient alpha of 0.965, which is deemed acceptable (Nunnally, 1978; Churchill, 1979) and suggests that the "measures were free from random error and thus reliability coefficients estimate the amount of systematic variance" (Churchill, 1979). Reliability analysis is well known as to test the 'degree of consistency between measures of the scale' (Mehrens \& Lehmann, 1987). When each factor (study variables) such as 'Food and Beverage Quality', 'Food and Beverage Variety', 'Service Quality', 'Price and Value Fairness', 'Atmospherics' and 'Customer Satisfaction' was

Table 1: Reliability of the study

\begin{tabular}{lll}
\hline Variables & Cronbach Alpha $(\boldsymbol{\alpha})$ & Number of Items \\
\hline Food and Beverage Quality & 0.923 & 9 \\
Food and Beverage Variety & 0.816 & 5 \\
Service Quality & 0.940 & 18 \\
Price and Value Fairness & 0.945 & 5 \\
Atmospherics & 0.916 & 16 \\
Customer Satisfaction & 0.878 & 7 \\
Overall & 0.965 & 60 \\
\hline
\end{tabular}

examined, all variables were found to be reliable with a coefficient alpha higher than 0.70 at aggregate level, the cut-off point (Nunnally, 1978; Churchill, 1979). The high alpha values indicated good internal consistency among the items, and the high alpha value for the overall scale indicated that convergent validity was met (Parsuraman, Berry, \& Zeithmal, 1991).

\subsection{Descriptive analysis}

Table 2 below illustrates that from the total sample size of 294, the percentage of respondents' gender consisted of $55.4 \%$ females and $44.6 \%$ males. Since the study was conducted in the university and most of the diners were students who were actually studying at Taylor's University, thus majority $(78.6 \%)$ of the respondents were the students who were mainly $(72.8 \%)$ in the age group of 17 to 24. Apart from students, the remaining respondents were academics (12.9\%) and admin staff (8.5\%). Among these respondents, 59.9\% were bachelor's and 19\% were master's or PhD level students. The remaining 21.1\% students were studying either for a diploma or foundation programs. The frequency analysis also showed that $41.5 \%$ of the respondents who dined at Temptations, were hospitality, tourism and culinary arts students (HTCA), followed by computers and information technology (11.2\%) and biosciences (10.2\%) students. The data also exhibits that the majority of respondents has eaten less than once a week (36.1\%) at Temptations restaurant, which was followed by those who dined at least once a week (17.3\%), twice a week (15\%), four times a week (15\%) and three times a week (12.6\%). There were only $4.1 \%$ of respondents who were the most regular patrons and dined in Temptations every day. The most significant reason to eat at temptations restaurant was found to be the price (55.8\%), which indicates that the prices charged at Temptations are much more reasonable as compared to the other commercial restaurants located at the Taylor's University Lakeside campus. The other significant reason for the respondents was food $(29.6 \%)$. For the remaining $14.6 \%$ of respondents, service quality, restaurant ambience, meetings and promotions were the least significant reasons to dine in Temptations restaurant. For the majority of the respondents, their average bill at temptations was less than 8 Malaysian Ringgit. This again shows that the prices at Temptations are much cheaper compared to other restaurants at the lakeside campus. For $19 \%$ of the respondents, their average spending was between RM 9 to 12 , and $9.5 \%$ respondents spend between RM 13 and 15 . Only $2.4 \%$ of respondents spend more than RM15. The 
Table 2: Details of demographics $(n=294)$

\begin{tabular}{|c|c|c|}
\hline & $\begin{array}{l}\text { Freq } \\
\text { (F) }\end{array}$ & $\begin{array}{l}\text { Percentage } \\
(\%)\end{array}$ \\
\hline \multicolumn{3}{|l|}{ Gender } \\
\hline Male & 131 & 44.6 \\
\hline Female & 163 & 55.4 \\
\hline Total & 294 & 100.0 \\
\hline \multicolumn{3}{|l|}{ Age } \\
\hline $17-24$ & 214 & 72.8 \\
\hline $25-32$ & 34 & 11.6 \\
\hline $33-40$ & 28 & 9.5 \\
\hline $41-48$ & 13 & 4.4 \\
\hline $49-56$ & 3 & 1.0 \\
\hline Above 57 & 2 & 0.7 \\
\hline Total & 294 & 100.0 \\
\hline \multicolumn{3}{|l|}{ Education } \\
\hline Foundation & 25 & 8.5 \\
\hline Diploma & 37 & 12.6 \\
\hline Degree & 176 & 59.9 \\
\hline Master / PhD & 56 & 19.0 \\
\hline Total & 294 & 100.0 \\
\hline \multicolumn{3}{|l|}{ School / Department } \\
\hline TCHT & 122 & 41.5 \\
\hline SABD & 19 & 6.5 \\
\hline SOCIT & 33 & 11.2 \\
\hline Business & 15 & 5.1 \\
\hline Engineering & 14 & 4.8 \\
\hline Medicine & 1 & 0.3 \\
\hline Law & 5 & 1.7 \\
\hline ADP & 22 & 7.5 \\
\hline Biosciences & 30 & 10.2 \\
\hline Pharmacy & 4 & 1.4 \\
\hline Others & 29 & 9.9 \\
\hline Total & 294 & 100.0 \\
\hline \multicolumn{3}{|l|}{ Occupation } \\
\hline Student & 231 & 78.6 \\
\hline Academician & 38 & 12.9 \\
\hline Admin / Manager & 25 & 8.5 \\
\hline Total & 294 & 100.0 \\
\hline \multicolumn{3}{|c|}{ Frequency of Dining in Temptations } \\
\hline Everyday & 12 & 4.1 \\
\hline Less than Once a Week & 106 & 36.1 \\
\hline Once a Week & 51 & 17.3 \\
\hline Twice a Week & 44 & 15.0 \\
\hline Three times a Week & 37 & 12.6 \\
\hline Four times or more & 44 & 15.0 \\
\hline Total & 294 & 100.0 \\
\hline
\end{tabular}

\begin{tabular}{|c|c|c|}
\hline & $\begin{array}{l}\text { Frequ } \\
\text { (F) }\end{array}$ & $\begin{array}{l}\text { Percentage } \\
(\%)\end{array}$ \\
\hline \multicolumn{3}{|c|}{ Most significant reason to dine in Temptations } \\
\hline Food & 87 & 29.6 \\
\hline Service Quality & 4 & 1.4 \\
\hline Restaurant Ambience & 8 & 2.7 \\
\hline Price & 164 & 55.8 \\
\hline Meetings & 7 & 2.4 \\
\hline Promotions & 24 & 8.2 \\
\hline Total & 294 & 100.0 \\
\hline \multicolumn{3}{|l|}{ Average check per time } \\
\hline Less than RM 8 & 203 & 69.0 \\
\hline RM 9-12 & 56 & 19.0 \\
\hline RM 13-15 & 28 & 9.5 \\
\hline More than RM 15 & 7 & 2.4 \\
\hline Total & 294 & 100.0 \\
\hline \multicolumn{3}{|c|}{ Dining companion in Temptations } \\
\hline Alone & 41 & 13.9 \\
\hline With friends & 221 & 75.2 \\
\hline With colleagues & 32 & 10.9 \\
\hline Total & 294 & 100.0 \\
\hline \multicolumn{3}{|c|}{ Recommendation for Temptations } \\
\hline Yes & 231 & 78.6 \\
\hline No & 63 & 21.4 \\
\hline Total & 294 & 100.0 \\
\hline
\end{tabular}

majority $(75.2 \%)$ of the respondents being the students, they dined in Temptations with their friends, $10.9 \%$ of respondents dined with their colleagues or dined alone (13.9\%). On being asked if they will recommend Temptations restaurant to their friends or colleagues to dine here, $78.6 \%$ of respondents were happy with Temptations and responded positively, while $21.4 \%$ responded negatively.

\subsection{Correlation analysis}

In the present study, correlation analysis was employed since "correlation analysis involves measuring the closeness of the relationship between two or more variables; it considers the joint variation of two measures" (Churchill A. G., 1995; Pallant, 2010). The correlation analysis was used for independent variables 'F\&B Quality', 'F\&B Variety', 'Service Quality', 'Price and Value Fairness' and 'Atmospherics' towards dependent variable 'Customer Satisfaction' to test the hypotheses mentioned earlier.

In Table 3, the results of correlation analysis are significant at the 0.01 level. When the correlation coefficients 
Table 3: Correlation analysis

\begin{tabular}{|c|c|c|c|c|c|c|}
\hline \multicolumn{7}{|l|}{ Variables } \\
\hline Scales & 1 & 2 & 3 & 4 & 5 & 6 \\
\hline F\&B Quality & 1 & & & & & \\
\hline F\&B Variety & 0.654 & 1 & & & & \\
\hline Service Quality & 0.578 & 0.567 & 1 & & & \\
\hline Price \& Value Fairness & 0.615 & 0.517 & 0.519 & 1 & & \\
\hline Atmospherics & 0.725 & 0.559 & 0.617 & 0.582 & 1 & \\
\hline Customer Satisfaction & 0.268 & 0.185 & 0.236 & 0.191 & 0.396 & 1 \\
\hline
\end{tabular}

Note: All the correlations are significant at the 0.01 level (two-tailed).

matrix between study variables is examined, no correlation coefficient is equal to 0.90 or above. This examination provides support for the discriminant validity of this study, which means that all the constructs are different/ distinct (Amick \& Walbery, 1975). This also indicates that there is a strong positive correlation between the variables, hence, all the five hypotheses were also found to be significant.

The objectives of the study were to have a better understanding of the relationships among experiences and customer satisfaction in the university cafeteria. The outcome of the correlation showed that customers' satisfaction with university cafeteria is profoundly influenced by food and beverage quality. This finding is emphatically connected with those of previous authors (Hwang, Eves, \& Desombre, 2003; Kim \& Kim, 2004; Qin \& Prybutok, 2009; Raman \& Chinniah, 2011). Food and beverage quality features, for example, cleanliness while serving to clients, quality offered and menu variety are viewed as vital by university students and staffs eating at the cafeteria. The result additionally represents that customers' satisfaction with university cafeteria is especially affected by price and value fairness. This is in accordance with previous findings (Herrmann, Xia, Monroe, \& Huber, 2007; Martin-Consuegra, Molina, \& Esteban, 2007; Oliver \& Swan, 1989), proposing price value sensibility ends up being more basic to students as they get more information from the menus to make value relationships and conclusions whether the price is higher or lesser in association of the food and beverage offered by the university cafeterias.

\section{Conclusion}

The study revealed that students' satisfaction with the university cafeteria has positive relationship with all the different factors, for e.g., food and beverage quality, variety, price value fairness, service quality and the atmospherics, used in this study. It is in this way critical for university cafeteria administrators to continue enhancing the quality of food and beverage served to the clients to increase their satisfaction level. Moreover, an attractive menu, with different food varieties, at a reasonable price should be offered to the customers and served in an appropriate ambience that can energise their enthusiasm for dining at the university cafeteria. The results showed that food and beverage quality and service quality have a significant relationship with customer satisfaction. This was supported by previous studies. For instance, Ha and Jang (2010) and Hyun (2010) confirmed from their study that food and beverage quality and service quality have positive and significant relationship with consumer satisfaction in university cafeteria service. Similarly, the findings of the present study support the positive affiliation of food and service quality with customer satisfaction. Thus, the present study distinguished the connotation among perceived quality, service quality and satisfaction with regards to a university cafeteria.

This study has significant ramifications for research and practice in the planning and designing of new promoting approaches and procedures for university cafeterias, contingent upon their target market. One of the significant ramifications of this study is that food and beverage quality and price value fairness are the critical components that the cafeteria administrators must consider regardless of whether students, staff or the general public, who visit and dine at the cafeteria. The university cafeteria administrators must look into staff training and development, provide fresh foods in the menu choices, and provide an alluring and comfortable ambience. Second, this study evaluates the price by analysing the customers' general impression of the total value they received from the university cafeteria. The results demonstrated that price is an essential variable to gauge general fulfilment and expectation among customers' university cafeterias. Although various researchers have effectively 
highlighted and demonstrated the significance of price in food and beverage outlets to satisfy customers, the findings of this study hypothetically re-confirm the correlation between price, value and customer satisfaction university cafeterias.

With educational expenses increasing each year and expenses of various other facilities increasing considerably, students' requests and expectations are also increasing the services and facilities that they receive. In the event that universities neglect to take an interest in their universal services meticulously, in which food and beverage services can have a distinctive impact, disappointed students might perceive the total product offered as below their expectations. This might have an impact on their studies and will force them to re-evaluate their decision of choosing a particular university. It is, therefore, essential that the students' food requirements need be checked intermittently whereby university executives can enhance the product delivery and, subsequently, student's retention objectives.

Findings stated that the food and beverage choices offered were satisfactory but it can be enhanced further by the cafeteria administrators. Thus, it is suggested that cafeteria operatives introduce strategies, such as cycle menu planning. Cycle menu planning is a series of food menus that are planned by the food service operators for a specific period of time. The cafeteria management should also look into offering more choices catering to the vegetarians and the international clientele as there many international students and staff working in the university.

\section{Limitations}

A few of the constraints and recommendations for future research of this study ought to be noted. Most importantly, this study did not have a large sample size. Hence, the the smaller sample size will most likely be unable to be extrapolated to the larger populace. Likewise, this study was conducted in Taylor's university cafeteria, and its outcomes may not be valuable for other universities and colleges. As various geographical and demographical settings may change the consequences of the study considerably, future studies could include a variety of universities and colleges to understand the perception of the staff and students about their experiences towards university cafeteria. Future studies may also look into the perception and experiences of the local and international students and staff towards university cafeteria separately.

\section{References}

[1] Amick, D. J. \& Walberg, H. J. (1975). Introductory Multivariate Analysis, California: McCutchan Publishing Corporation, ch. 7

[2] Amelia, M., \& Garg, A. (2016). First Impression in a Fine Dining Restaurant. A Study of ' $C$ ' Restaurant in Tampere, Finland. European Journal of Tourism, Hospitality, and Recreation, 7(2), 100-111. doi:https://doi.org/10.1515/ ejthr-2016-0012

[3] Andaleeb, S., \& Caskey, A. (2007). Satisfaction with Food Services: Insight from a College Cafeteria. Foodservice Business Research Journal, 10(2), 51-65

[4] Baharun, R, Awang, Z \& Padlee, S.F. (2010), International students' choice criteria for selection of higher learning in Malaysian private universities, African Journal of Business Management, 5(12), 4704-4714

[5] Bisogni, C. A., Falk, L. W., Madore, E., Blake, C. E., Jastran, M., Sobal, J., \& Devine, C. M. (2007). Dimensions of Everyday Eating and Drinking Episodes. Appetite, 48(2), 218-231

[6] Bolton, R. N., \& Shankar, V. (2003). An Empirically derived Taxonomy of Retailer Pricing and Promotion Strategies. Journal of Retailing, 79(4), 213-224

[7] Chang, M. D., Suki, N. M., \& Nalini, A. (2014). A Structural Approach on Students' Satisfaction Level with University Cafeteria. Asian Social Science, 10(18), 202-209

[8] Churchill, A. G. (1995). Marketing Research: Methodological Foundations (6th ed.). New York: Dryden Press

[9] Churchill, G. A. (1979). Marketing Research: Methodological Foundations. Hinsdale, Illinois: Dryden Press

[10] DellaValle, D. M., Roe, L. S., \& Rolls, B. J. (2005). Does the consumption of caloric and non-caloric beverages with a meal affect energy intake? Appetite, 44(2), 187-193

[11] Deshpande, S., Basil, M. D., \& Basil, D. Z. (2009). Factors influencing healthy eating habits among college students: An application of the health belief model. Health Marketing Quarterly, 26(2), 145-164

[12] Dollah S.N., Mansor, N., Mohamed, M. (2012). Exploring the major determinants of student satisfaction on university cafeteria food services: A Malaysian case. Interdisciplinary Journal of Research in Business 2(7), 62-73

[13] Flegal, K. M., Carroll, M. D., Ogden, C. L., \& Curtin, L. R. (2010). Prevalence and Trends in Obesity among US Adults, 1999- 2008. The Journal of the American Medical Association, 303(3), 235-241

[14] Garg, A. (2014). Mechanic clues vs. humanic clues: Students' perception towards service quality of fast food restaurants in Taylor's University campus. Procedia - Social and Behavioural Sciences, 144(1), 164-175

[15] Ha, J., \& Jang, S. (2010). Effects of service quality and food quality: The moderating role of atmospherics in an ethnic restaurant segment. International Journal of Hospitality Management, 29(3), 520-529. doi:10.1016/j. ijhm.2009.12.005

[16] Hensley, R. L., \& Sulek, J. (2007). Customer satisfaction with waits in multi-stage services. Managing Service Quality, 17(2), 152-173

[17] Herrmann, A., Xia, L., Monroe, K. B., \& Huber, F. (2007). The influence of price fairness on customer satisfaction. Journal of Product \& Brand Management, 16(1), 49-58 
[18] Hwang, L., Eves, A., \& Desombre, T. (2003). Gap analysis of patient meal service perceptions. International of Health Care Quality Assurance, 16(9), 143-153

[19] Hyun, S. (2010). Predictors of relationship quality and loyalty in the chain restaurant industry. Cornell Hotel and Restaurant Administration Quarterly, 51(2), 251-267

[20] Inkumsah, W. A. (2011), Measuring Customer Satisfaction in the Local Ghanaian Restaurant Industry, European Journal of Business and Management, 3(2), 153-166

[21] Jaeger, S. R., Marshall, D. W., \& Dawson, J. (2009). A quantitative characterization of meals and their contexts in a sample of 25 to 49-year-old Spanish people. Appetite, 52(2), 318-327

[22] Joung, H., Lee, D., Kim, H., Ahn, J., \& Huffman, L. (2011). Evaluating on-campus dining service using importance-performance analysis. Retrieved from http://scholarworks. umass.edu/: http://scholarworks.umass.edu/gradconf_ hospitality/2011/Presentation/58/

[23] Kim, W. G., \& Kim, H. B. (2004). Measuring customer-based restaurant brand equity. Cornell Hotel \& Restaurant Administration Quarterly, 45(2), 115-131

[24] Koster, E. P. (2009). Diversity in the determinants of food choice. A psychological perspective. Food Quality and Preference, 20(2), 70-82

[25] Lee, S.-H., Liaw, M. S., Lee, K.-S., \& Rha, Y.-A. (2016). International Students' Perception on University Cafeteria in Malaysia. Culinary Science \& Hospitality Research, 22(6), 24-32

[26] Lee, S. (2004). College students' perception and preference of brand name food services in university dining operations. (Published Master Thesis). Stillwater, Oklahoma: Faculty of the Graduate College of the Oklahoma State University

[27] Li, G. (2008). Difficulties facing university catering service work and responses. Science and Technology Information, 14, 72-73

[28] Martin-Consuegra, D., Molina, A., \& Esteban, A. (2007). An integrated model of price, satisfaction, and loyalty: An empirical analysis in the service sector. Journal of Product \& Brand Management, 16(7), 459-468

[29] McCall, M., \& Lynn, A. (2008). The effects of restaurant menu item descriptions on perceptions of quality, price, and purchase intention. Journal of foodservice business research, 11(4), 439-445

[30] Mehrens, W. A., \& Lehmann, I. J. (1987). Using Standardised Tests in Education. New York: Longman

[31] Meyer, M. K., \& Conklin, M. T. (1998). Variables Affecting High School Students' Perceptions of School Foodservice. Journal of the American Dietetic Association, 98(12), 1424-1429

[32] Nadzirah, S., Ab-Karim, S., Ghazali, H., \& Othman, M. (2013). University foodservice: An overview of factors influencing the customers' dining choice. International Food Research Journal, 20(3), 1459-1468

[33] Namkung, Y., \& Jang, S. (2008). Are highly satisfied restaurant customers really different? A quality perception perspective. International Journal of Contemporary Hospitality Management, 20(2), 142-155. Doi: $10.1108 / 09596110810852131$

[34] Ng, Y. (2005). Study of the impact of customer satisfaction on intention to return and return intention, and word-of-mouth endorsement in university dining operations. (Published master thesis). Oklahoma. USA: Graduate College of Oklahoma State University, Stillwater

[35] Norhati, I., \& Nur Hafisah, F. (2013). Informal Setting for Learning on Campus: Usage and preference. Procedia - Social and Behavioural Sciences, 105, 344-351

[36] Nunnally, J. C. (1967). Psychometric theory. New York: McGraw-Hill

[37] Nunnally, J. C. (1978). Psychometric Theory. New York: Mcgraw-Hill

[38] Oh, H. (2000). Diners' perception of quality, value, and satisfaction: A practical viewpoint. Cornell Hotel and Restaurant Administration Quarterly, 41(3), 58-66

[39] Oliver, R. L., \& Swan, J. E. (1989). Consumer perceptions of interpersonal equity and satisfaction in transactions: A field survey approach. Journal of Marketing, 53(2), 21-35

[40] Pallant, J. F. (2005). SPSS Survival Manual (2nd ed.). Crows Nest, New South Wales, Australia: Allen \& Unwin

[41] Parsuraman, A., Berry, L. L., \& Zeithmal, V. A. (1991). Refinement and Reassessment of the SERVQUAL scale. Journal of Retailing, 67(4), 420-450

[42] Paswan, A. K., Spears, N., \& Ganesh, G. (2007). The Effect of Obtaining One's Preferred Service Brand on Consumer Satisfaction and Brand Loyalty. Journal of Services Marketing, 21(2), 75-87

[43] Qin, H., \& Prybutok, V. R. (2009). Service Quality, customer satisfaction and behavioural intentions in the fast-food restaurant. International Journal of Quality and Service Sciences, 1(1), 78-95

[44] Raman, S., \& Chinniah, S. (2011). An investigation on higher learning student's satisfaction on food services at the university cafeteria. Journal of Research in Commerce, IT \& Management, 1(2), 12-16

[45] Saglik, E., Gulluce, A., Kaya, U., \& Ozhan, C. (2014). Service quality and customer satisfaction relationship: A research in Erzurum Ataturk university refectory. American International Journal of Contemporary Research, 4(1), 100-117

[46] Schmitt, N. (1996). Uses and abuses of coefficient alpha. Psychological Assessment, 8(4), 350-353

[47] Soriano, D. (2003). The Spanish restaurant sector: Evaluating the perception of quality. Journal of Service Industries, 23(2), 183-194

[48] Story, M., Kaphingst, K. M., Robinson-O’Brien, R., \& Glanz, K. (2008). Creating Healthy Food and Eating Environments: Policy and Environmental Approaches. Annual Review of Public Health, 29(1), 253-272

[49] Tam, J. L. (2008). Brand Familiarity: Its effect on satisfaction evaluations. Journal of Services Marketing, 22(1), 3-12

[50] Tan, Q., Oriade, A., Fallon, P. (2014). Service quality and customer satisfaction in Chinese fast food sector: A proposal for CFFRSERV. Advances in Hospitality and Tourism Research 2(1), 30-53

[51] Woo, G. K., Ng, C. N., \& Kim, Y. S. (2009). Influence of Institutional DINESERV on Customer Satisfaction, Return Intention, and Word-of-Mouth. International Journal of Hospitality Management, 28, 10-17

[52] Xi, L., \& Shuai, Z. (2009). Investigation of customer satisfaction in student food service. An example of student cafeteria in NHH. Quality and Service Sciences International Journal, 1(1), 113-124 
[53] Yilmaz, E. (2008). Toplam Kalite Yönetimi ve İnsan Merkezli Kütüphanecilik. Symposium of scientific communication and knowledge management (Gazi Üniversitesi, Ankara, 12-14 September 2006) (pp. 185-211). Ankara: Üniversite ve Araştırma Kütüphanecileri Derneği

[54] Yuksel, A., \& Yuksel, F. (2002). Measurement of tourist satisfaction with restaurant services: A segment-based approach. Journal of Vacation Marketing, 9(1), 52-68

Anshul Garg is a senior lecturer in the faculty of Hospitality, Food and Leisure Management at Taylor's University, Malaysia. His research interest includes Service Quality, Service Clues and Hospitality Service. He has presented his work at various seminars and international conferences and also successfully published in various international refereed journals like European Journal of Tourism, Hospitality and Recreation, Asian Journal of Tourism and
Hospitality Research, Asia-Pacific Journal of Innovation in Hospitality and Tourism, International Journal of Hospitality \& Tourism Systems.

Dr. Jeetesh Kumar, Jeetesh is a senior lecturer in the faculty of Hospitality, Food \& Leisure Management at Taylor's University Malaysia. His area of research is currently customer satisfaction in F\&B industry. His publications have appeared in different Journals such as; Journal of Tourism, Event Management, International Interdisciplinary Business-Economics Advancement Journal, Asia-Pacific Journal of Innovation in Hospitality and Tourism, Journal of Tourism, Hospitality Malaysian Online Journal of Educational Management \& Culinary Arts, TEAM Journal of Hospitality and Tourism. 